\title{
VER-SUS project: Influences on the training and performance of nurses
}

\author{
Projeto VER-SUS: Influências na formação e atuação do enfermeiro \\ Proyecto VER-SUS: Influencias en la formación y actuación del enfermeiro
}

\section{Fernanda Almeida Fettermann', Elisabeta Albertina Nietsche", Marlene Gomes Terra", Cléton Salbego", Odete Messa Torres"', Tierle Kosloski Ramos"II}
' Universidade Federal do Rio Grande do Sul. Porto Alegre, Rio Grande do Sul, Brazil.
"Universidade Federal de Santa Maria. Santa Maria, Rio Grande do Sul, Brazil.
"'U Universidade Federal do Pampa. Uruguaiana, Rio Grande do Sul, Brazil.

\section{How to cite this article:}

Fettermann FA, Nietsche EA, Terra MG, Salbego C, Torres OM, Ramos TK. VER-SUS project: Influences on the training and performance of nurses. Rev Bras Enferm [Internet]. 2018;71(6):2922-9. DOI: http://dx.doi.org/10.1590/0034-7167-2017-0868

Submission: 02-14-2018 Approval: 04-20-2018

\begin{abstract}
Objective: To analyze the influences of the Vivências e Estágios na Realidade do Sistema Único de Saúde (Brazilian Unified Health System), in the training and performance of nurses. Method: A qualitative study was carried out with 14 nurses who participated in the VER-SUS project in Rio Grande do Sul State. The data were collected through a semi-structured interview technique. The data were analyzed, interpreted and discussed, through the technique of Content Analysis. Results: The categories "VER-SUS Influences on Nursing Training for SUS" and "VER-SUS Contributions for Nurses Performance in the SUS" were highlighted. Final considerations: It was possible to identify the influences of the VER-SUS project in the training and performance of the nursing professionals, pointing out the revision of the Pedagogical Projects of Course and the preparation of the teachers, as a way to carry out the training with emphasis in the Brazilian Unified Health System.
\end{abstract}

Descriptors: Nursing; Unified Health System; Continuous Training; Education; Education in Nursing.

\section{RESUMO}

Objetivo: Analisar as influências das Vivências e Estágios na Realidade do Sistema Único de Saúde, na formação e atuação dos enfermeiros. Método: Estudo qualitativo desenvolvido com 14 enfermeiros que durante sua graduação, participaram do projeto VER-SUS no estado do Rio Grande do Sul. A coleta dos dados ocorreu por meio da técnica de entrevista semi-estruturada. Os dados foram analisados, interpretados e discutidos, por meio da técnica de Análise de Conteúdo. Resultados: Destacaram-se as categorias "Influências do VER-SUS na formação do enfermeiro para o SUS" e "Contribuições do VER-SUS para a atuação do enfermeiro no SUS". Considerações finais: Foi possível identificar que o projeto teve influências na formação e atuação dos profissionais enfermeiros. A revisão dos Projetos Pedagógicos de Curso e o preparo dos docentes, é indicado como um caminho para efetivar a formação com ênfase no Sistema único de Saúde.

Descritores: Enfermagem; Sistema Único de Saúde; Formação Continuada; Educação; Educação em Enfermagem.

\section{RESUMEN}

Objetivo: Análisis de las influencias de las vivencias y pasantías en la Realidad del Sistema Único de Salud, en la formación y actuación de los enfermeros. Método: Estudio cualitativo, desarrollado con 14 enfermeros que, durante su graduación, participaron del proyecto VER-SUS en el estado de Rio Grande do Sul. La recolección de los datos ocurrió por medio de la técnica de entrevista semiestructurada. Los datos fueron analizados, interpretados y discutidos, por medio de la técnica de Análisis de Contenido. Resultados: Se destacaron las categorías "Influencias del VER-SUS en la formación del enfermero para el SUS", "Influencias del VER-SUS en la formación del enfermero para el SUS" y "Contribuciones del VER-SUS para la actuación del enfermero en el SUS". Consideraciónes finales: Fue posible identificar las influencias del proyecto VER-SUS en la formación y actuación de los profesionales enfermeros, apuntando la revisión de los Proyectos Pedagógicos de Curso y la preparación de los docentes, como un camino para efectivizar la formación con énfasis en el Sistema Único de Salud.

Descriptores: Enfermería; Sistema Único de Salud; Educación Continua; Educación; Educación en Enfermería. 


\section{INTRODUCTION}

The traditional training models of undergraduate health courses are increasingly dysfunctional for satisfactory performance in current health services. In the nursing work universe, there is an emerging need to qualify these professionals with a view to serving users, especially those of a public nature. In the meantime, a necessary transformation of the profile of future health workers is proposed, through the adoption of strategies directed to the field of training and development of professionals, built on the principles and guidelines of the Brazilian Unified Health System (SUS - Sistema Único de Saúde), besides being based on the expanded concept of health; in the use of methodologies that consider health work as the structuring axis of the activities and in the multiprofessional work ${ }^{(1-2)}$.

Changes in our society, in public health policies and in education have triggered determinants factors for the (re)construction of training of nursing professionals engaged in intervening in the change of health indicators. In this sense, the training of the nurse has made possible an emancipatory education by allowing daily reflection, questioning and social transformation ${ }^{(2)}$.

In view of this new professional profile, in 2001, the Diretrizes Curriculares do Curso de Graduação (DCG- freely translated as Undergraduate Curricular Guidelines) in Nursing were instituted. These guidelines, based on skills, define the training of nurses as generalists and human beings capable of learning to grasp, position themselves in a critical and reflexive way in the face of reality and meet the needs of the population according to the principles governing the Brazilian Unified Health System (SUS) ${ }^{(3-4)}$.

In this context, in order to meet social needs and professional training, it is essential to carry out strategies that promote teaching-learning processes that are consistent with this new professional profile and that enable changes in the practices of health professionals. Thus, the curricular and extracurricular activities carried out by students in the Health area should be based on a logic of development of potentialities for a critical and reflexive thinking about their practices, seeking to understand the subjects' needs, aiming at a comprehensive and qualified care that meet the health needs ${ }^{(4)}$. These activities, carried out in an articulated manner between educational institutions, health services management, social control and the students themselves, make it possible to (re)know the reality of health and the organization of the management system and health care ${ }^{(4)}$.

Among these strategies, the Project "Vivências e Estágios na Realidade do Sistema Único de Saúde" (VER-SUS) stands out; an initiative that provides students the experience of the reality of SUS, thus contributing to the training of professionals critical and sensitive to the needs of the Brazilian population and to the strengthening of $S \cup S^{(4)}$. This project of the Ministry of Health allows the living-trainees to know the functioning of the system, the importance of the action and interaction of a multiprofessional team, the dialogue of different professions, enabling cultural, intellectual and affective exchange ${ }^{(5-6)}$.

The VER-SUS project started in 2003 and was carried out in 20 states and 180 municipalities, involving approximately 20 thousand students from different areas, with a greater emphasis on Health ${ }^{(7-8)}$. The reflexes are felt in the most intense interaction with SUS services, social movements, professionals and users, which help to experience (re)think about health practices, the needs of the population, as well as the role of professionals and managers in production of a more integrated and qualified health.

Through a multiprofessional experience, the VER-SUS allows students 15 days of immersion and knowledge of a municipal or state health network. It is about the interaction of the students among themselves, with managers, health workers, users and institutions of Higher Education; an interaction that fosters debate and knowledge about aspects of system management, care strategies, the exercise of social control and health education processes( ${ }^{(6)}$.

For Nursing, immersion in SUS settings is a strategy that enables students to develop skills and competences distinct from traditional training, preparing them as best qualified nurses for health performance ${ }^{(4)}$. This immersion is necessary in the training context, because it gives the students an educational process that questions the formal curriculum, through activities understood as experiences. In VER-SUS, as professionals in training, it is possible for students to reflect knowing, seeing and doing (re)creating new praxis.

In this context of academic-professional training, the VER-SUS allows students to know the SUS, its laws and guidelines, making it part of the process through the insertion in health services full of paradigms, demystifying public health. The experiences of VER-SUS have been presented as initiatives that seek to provide possibilities of unrest, annoyances and curiosities among those involved, regarding the health system. Thus, it is considered that the VER-SUS has numerous powers, which include the encouragement of student protagonism in its training process, not only individual, but above all, collective ${ }^{(8)}$.

The feasibility of this study arises from the researchers' experience with the VER-SUS project, where many questions emerged: "What are the influences of the Vivências e Estágios na Realidade do Sistema Único de Saúde project, in the training and performance of nurses?". Therefore, because they realize that this professional must go beyond traditional knowledge and action, that is, he must think of an expansion of the field of health actions, valuing and seeking popular knowledge, social control, promotion of individual and collective health, the constant interlocution between the triad theory, practice and experience, without breaking with their social connections, (re) defining their tools and the object of health work ${ }^{(4)}$.

In this context, this study had as objective to analyze the influences of the Vivências e Estágios na Realidade do Sistema Único de Saúde project (VER-SUS), in the training and performance of the nurses.

\section{OBJECTIVE}

To analyze the influences of the Vivências e Estágios na Realidade do Sistema Único de Saúde project, in the training and performance of the nurses.

\section{METHOD}

\section{Ethical aspects}

The project was approved by the Research Ethics Committee of a Federal University of Rio Grande do Sul State. The requirements contained in Resolution 466/12 of the National Health Council 
(Conselho Nacional de Saúde) were respected. The participants signed the Informed Consent Form. In order to guarantee confidentiality and anonymity, the following letters were used: N (nurse), followed by the numerical identification corresponding to the order in which the collection was performed, e.g., N1, N2 and so on.

\section{Design and research setting}

It is an exploratory and descriptive research ${ }^{(9)}$, with a qualitative approach ${ }^{(10)}$.

\section{Study setting}

The study was developed with 14 nurses who, during their graduation, participated in the VER-SUS project in Rio Grande do Sul State (RS). Geographically, the study was developed in seven municipalities, as the place where nurses worked professionally during data collection. The identification of these cities occurred from the contact with the participants.

\section{Data source}

The identification of the participants occurred, initially, through formal contact with the National Coordination of the Project, which made available the list of participants of the project VER/ SUS, edition 2012/RS. From this, the search of these participants in the Platform Lattes of the Brazilian National Council for Scientific and Technological Development (CNPq - Conselho Nacional de Desenvolvimento Científico e Tecnológico), in their curricula and, also, in the social networks was carried out. At the same time, e-mail was sent to each subject, informing the objectives of this study and requesting that they inform their current condition, that is, of being a student or nurse. If she was a nurse, she was asked to declare her interest in participating in the study and to inform her in which city she was working. The signing of the Informed Consent Term occurred at the meeting, previously scheduled at the date, time and place of the participant's choice. With this survey, it was identified that 82 nursing students participated in the project in 2012 and of these, 17 were acting professionally.

In view of the large number of nursing students who took part in the experiment in 2012 in Rio Grande do Sul State, the following inclusion criteria were adopted: that the academic had passed a degree in the nursing course until the end of the second semester of 2013 and that, in the period of data collection, was working professionally as a nurse or in Residency programs; should also be working and residing in Rio Grande do Sul State. Exclusion Criteria: Nurses who were not located ${ }^{(4)}$.

\section{Collection and organization of data}

Data were collected between October 2014 and January 2015. Data collection was performed using a semi-structured interview technique. The interviews were recorded in a cellular recorder (digital recording) and, later, the speeches were transcribed, verbatim, in full, aiming to preserve the verbal expressions of the subjects.

\section{Data analysis}

The data were analyzed, interpreted and discussed, followed by the Content Analysis technique ${ }^{(11)}$, which consisted of three chronological poles, such as pre-analysis, material exploration and treatment of results obtained and interpretation.

Pre-analysis: it occurred with the performance of the interviews, with exhaustive repetitions of reading, and then its transcription. This exhaustive reading was necessary, until the researcher appropriated the lines and remembered expressions that were of relevance for the analysis. With the reading of the speeches, an initial approximation was sought with the material collected; then the choice and organization of the documents for the analysis according to the research objectives were made so that the hypotheses could be identified and the study indicators elaborated to support the final interpretation and obtain an overview of the data collected ${ }^{(4)}$.

Exploration of material: At this stage, the material was printed and the lines cut into fragments. Afterwards, the clippings were grouped according to the similarity of the information. Thus, it was possible to list groups that emerged from nurses' statements. This grouping was performed with the collage of the fragments on colored A4 sheets, of which each color represented a group, identified with keywords. The following groups emerged: training, performance, paths, management, methodology, performance, knowing the SUS, motives, team and facilitator ${ }^{(4)}$.

Treatment of the results obtained and interpretation: this final analysis allowed the results to be treated in a more meaningful and valid way. To better identify the results, a more accurate reading of the cut-out sentences was made, highlighting, with color, the answers that had approximation, seeking to answer the objectives of the research. Afterwards, a critical reflection of the results was carried out to limit the categories discussed with authors who base this study ${ }^{(4)}$.

\section{RESULTS}

This study was composed of 14 nurses, of whom 10 were female and four were male, with ages between 23 and 39 years. As for academic training, the period ranged from 4.5 to 5 years. About the training institution, nine carried out their graduation in public institutions and five in private institutions of Higher Education ${ }^{(4)}$.

Regarding the professional performance of the participants, there was a predominance of the Multiprofessional Residency in Health: seven nurses, three of whom performed residency with emphasis on Family Health, two emphases on Mental Health, an emphasis on Obstetrics and one on Health Surveillance; the other six nurses work in hospital care and one in Family Health Strategy $(\mathrm{FHS})^{(4)}$.

Regarding the edition of the VER-SUS by the nurses, in 2012, it was evidenced that ten lived the experience in the summer edition. In relation to the others, two participated in the project in the winter edition and two in both editions. Thus, it was possible to identify that the majority of the participants of this study performed the VER-SUS in the summer edition, with an average time of 12 days of immersion ${ }^{(4)}$.

Data analysis resulted in two analytical categories: "VERSUS Influences on Nursing Training for SUS" and "VER-SUS Contributions for Nurses Performance in the SUS".

\section{VER-SUS Influences on Nursing Training for SUS}

It is noticed, among the nurses' speeches, a dichotomy between the guidelines of the Diretrizes Curriculares Nacionais (Curriculum 
and Content Standards) and the reality of nursing teaching, because the participants of the research affirm that the training is not directed to the SUS and pointed to the need for curricular reform ${ }^{(4)}$.

[...] health professionals are not trained specifically to work in the SUS. (N4)

I see that some institutions do not direct academics to SUS so much [...].But I think that all institutions should direct some training of professionals to the SUS. (N5)

[...] because during undergraduate degree we learned little about SUS. (N6)

[...] the way they introduce those who are trained in SUS, to the labor market, in this universities have to imply more through their curricular reforms that we see that something is happening [...]. (N8)

Also, on the nursing curriculum, the participants pointed to the fragmentation between theory and practice in teaching, arguing about not being able to make a connection between what was taught in the classroom and what they experienced in practice ${ }^{(4)}$ :

Maybe because who [the student] theorizes a lot cannot leave behind the table and go out a little to the street, and to account for what is happening. I think this I can bring a little bit today to the residency issue [...] I have a specialization training, but it is not a specialization in training in the classroom, but rather a specialization in service. (N1)

The interesting thing is that in VER-SUS no one brings you a theoretical content, an article or a book for you to understand what is happening, you go there (build in the group). (N14)

In this logic of breaking the dissociation between the theoretical training in relation to the demands of practical reality, the VER-SUS project enabled the nurses to know the reality of the Brazilian Unified Health System. This experience was described by the nurses as being positive, of emotional, personal growth and professional, as reported below ${ }^{(4)}$.

I think that VER-SUS is also an immense [...] emotional, personal and professional growth that everyone should attend during college. (N2)

VER-SUS has allowed me to get to know the reality, different locations, get to know the different types of people at work, and see what strategies I can use [...] to reach my health care goals. This is what VER-SUS has contributed more to me. (N4)

[...] the VER-SUS gave me this very important base to understand the Unified Health System as a space of dispute and as a space that needs struggle, social mobilization so that it remains public. I think those were [...] one of the main apprenticeships that the VER-SUS brought to me as a nurse. [...] I learned from this experience. (N7)

VER-SUS Contributions for Nurses Performance in the SUS With the speeches, it was possible to identify the contributions of the project in the professional performance. It is pointed out that the VER-SUS provided direct contact with the health system, which enabled nurses to know the operation of SUS and to dialogue with professionals. This experience had a beneficial effect on professional performance, as it triggered a need for nurses to be part of this system, to be active and restless in the quest to meet the needs of society ${ }^{(4)}$.

I do not say that it was from VER-SUS, but VER-SUS contributed a lot to my decision-making to make the selection [residency]. (N5)

Well, today I am in the residency, it is an influence of VERSUS, because I searched for a residency to experience even more this SUS reality and to be forming more and more for SUS [...]. (N7)

I stopped doing internships at the hospital and started to choose at health centers, [...] I changed my internship area a bit. (N9)

VER-SUS brought a passion for public health, because, you enter the college thinking that you will work in the hospital and in VER-SUS, you see other realities, then, this passion for SUS stays, because I saw how I can understand the SUS and think more about the collective. (N12)

Through participation in VER-SUS, nurses felt more confident and confident about their professional inclination towards public health. In this sense, they pointed to the project as an incentive for the Multiprofessional Residency Program.

Also, as a professional contribution, the experience of working with a multiprofessional team during the experience of VER-SUS is pointed out. According to the nurses, the academic training did not contribute to the team work and many stressed that the received was uniprofessional training, in other words, the learning is restricted to their own area of performance, not existing union with other professions.

The nurses described not knowing the role of other areas until the performance of the VER-SUS, which allowed an interaction, exchange of experience and articulation with other areas, as reported by the nurses ${ }^{(4)}$.

[VER-SUS][...] was very interesting to exchange with other professions that I did not know. (N1)

[VER-SUS] you have an exchange with other professions. I did not have it at graduation. (N5)

Graduation does not give you an interdisciplinary experience, and VER-SUS provides this, so you learn a lot [...]. (N6)

[...] was in the VER-SUS because in college it was only nursing group few chairs we did with other courses. Today I value these courses I know of their importance and how much I need them. (N9)

This interaction with students of other courses in the area of Health made it possible to know the role of each profession. For the nurses, knowing the work of other professionals contributed 
to their performance, since acting together with different areas of knowledge enables a performance without duplicity of actions, in which, cooperation prevails ${ }^{(4)}$.

\section{DISCUSSIONS}

The generalist training of health professionals in the face of constant accelerated updates in today's society demands that students be co-responsible for their training, seeking beyond the activities foreseen in the curricula. Thus, the search for extracurricular activities expands and strengthens professional training. In a study carried out with nursing students at a university in the United Kingdom, she pointed out that activities of this kind have a positive impact on the nursing curriculum. However, the search for these activities is still low among students ${ }^{(12-13)}$.

These activities enable the academic to train in Nursing with a humanist vision, through critical and reflexive thinking, able to know and intervene in the health-disease problems of the population, meeting the social needs of the latter's health, as recommended in the Curriculum and Content Standards of the Undergraduate Nursing course ${ }^{(3)}$.

In countries such as China, extracurricular activities are carried out through educational programs aimed at meaningful learning at work, where learning and teaching are incorporated into the daily life of organizations and work, in order to enable the qualification of professional practices ${ }^{(12)}$. These activities are encouraged in primary school education in order to provide students with ample training as a citizen and professional ${ }^{(14)}$.

Faced with the studies presented, it is possible to emphasize that extracurricular experiences are carried out by universities around the world. Studies carried out in Brazil and Mexico indicates that these activities, among the aforementioned powers, contribute to reduce the graduation rates of undergraduate degree in Nursing. Dropouts tend not to participate in Higher Education Institution activities that are not required for completion of the course, and students who complete the course are in some way more involved with Higher Education Institutions, performing activities which go beyond those related to the curriculum ${ }^{(15)}$. Thus, it is possible to point out that the immersion in extramural activities modifies the educational and institutional commitment of the student, besides contributing positively in the training of the individual, during the time that remains in the faculty ${ }^{(15)}$.

From the data of this research, it is evident the distance between the one proposed by Curriculum and Content Standards of the Undergraduate Nursing Course and what is being implemented by the Brazilian universities. Thus, it is necessary to revise the Nursing Course Pedagogical Projects as a way for a training based on professional preparation with competent, transformative, reflexive and reflection-in-action drivers, with SUS as interlocutor of this reformulation ${ }^{(4-17)}$.

This training, which limits the understanding of the SUS, generates a lack of knowledge about the system, which joins a negative view of a health system with no future. In addition, many use the system for their technical-scientific learning, however, they are not trained to act on it in a critical and reflective way ${ }^{(4-17)}$. Thus, it is possible to affirm the premise that the training of human resources for the SUS is one of the great challenges of this system ${ }^{(4)}$.

In order to achieve a training process in line with Curriculum and Content Standards, it is fundamental to rethink Nursing training, in addition to content disciplines, knowledge centered on technique and assessments through theoretical tests ${ }^{(4)}$. It is possible to rethink the profile of a new professional, trained and responsible for a fairer, egalitarian and better quality health care for all ${ }^{(16)}$. In this sense, it is important to emphasize that the definition of the nurse profile that will operate in SUS develops during the course of Nursing Undergraduate Course ${ }^{(18)}$.

Thus, during the reformulation of the CPP (Course Pedagogical Plan), it is necessary to have in view that the nursing professional is one of the great foundations for a quality SUS ${ }^{(4-5)}$. This reformulation needs to focus on the possibility of building articulated training processes in the world of work and practices that use active teaching-learning methodologies, contributing to active subject training in their own life course and work ${ }^{(4-18)}$.

This fragmentation between theory and practice disseminates knowledge and produces decontextualized knowledge, which does not consider the daily life of the actors who work in the health sector, either in teaching or care, making it impossible to find a meeting between knowing and seeing the world of SUS users ${ }^{(4)}$. In view of this, it is understood that the nursing academic faces the difficulty of finding an integrating axis between contents, when knowledge is fragmented and isolated; because the disciplines are clearly separated from each other ${ }^{(16)}$.

The training in Nursing requires the articulation between theory and practice, considering that the development of care is a sum that involves theoretical knowledge, contact with the other and relationships between people $\mathrm{e}^{(4-16)}$. Because of this, it is indispensable to combine scientific knowledge, acquired in the classroom, with the exercise, obtained in practical classes in the field of practical class or stage, so that the student develops actions that can approach him with the reality and their future professional life in order to reflect in a beneficial way as a nurse $\mathrm{e}^{(4-19)}$.

Seeking to improve health training, the Multiprofessional Health Residency (RMS - Residência Multiprofissional em Saúde) was created in 2005, this is a modality of graduation stricto sensu by work and, like VER-SUS, it is a space for development of the actions of Permanent Education in Health (EPS - Educação Permanente em Saúde), which can constitute as a potential device to promote the changes intended by health professionals in order to consolidate SUS principles ${ }^{(20)}$.

RMS is a strategy for the dissemination of EPS among health professionals, encompassing users, teachers and students. In this sense, it is noted that working from the perspective of EPS, whose ideology proposes interprofessional work and transformations in the field of Health, means accepting that changes in training and health depend on several factors related to the current paradigms ${ }^{(21)}$.

The tendency of professionals in each area to work in isolation and independent of others expresses their long and intense training also isolated and circumscribed to their own area of activity. However, authors ${ }^{(5)}$ argue that Interprofessional Education (IPE) opportunities contribute to the training of health professionals 
better prepared for integrated team work, in which collaboration and recognition of the interdependence of areas prevails in the face of competition and fragmentation. It is noted that the debate on IPE and Interprofessional Practice (IPP) deserves to always take place in an integrated way ${ }^{(22)}$.

With regard to teamwork, VER-SUS provides an interpersonal education, where students learn interactively about roles, knowledge and skills of other professionals, and contributes to the training of professionals better prepared for integrated teamwork ${ }^{(4)}$. This vision of collective work seeks to extinguish the tendency of professionals to act in isolation and independent of others, expressed in their long and intense training also isolated and circumscribed to their own area of activity. In this context, the interdependence of areas prevails over competition and fragmentation ${ }^{(4-22)}$.

In this context, it is understood that the multiprofessional work takes place from the perspective of a comprehensive and resolute approach, which allows the planning of more effective health actions. However, this construction of cooperative work implies overcoming many obstacles. The first step in overcoming these barriers built around different areas of knowledge must begin with the construction of integrated curricula ${ }^{(22)}$. The integrated curriculum is a dynamic articulation strategy between the basic and clinical cycle, between teaching, service and community, and between practice and theory ${ }^{(23)}$. This integration is understood not simply as the sum of the parts or grouping of objects distinct from different parts, but rather as the unity that must exist between the various disciplines and their forms of knowledge ${ }^{(4-24)}$.

From this perspective, it is possible to affirm that the lack of interaction in health training results in professionals alienated from each other, hindering efficient teamwork with good communication and agility in face of the professional situations that will be exposed. The operation of interactive, collective and shared work is fundamental for the reorganization of Health Care, since this relationship of different dimensions contributes to the emergence of actions resulting from the transformation of this new work process ${ }^{(25)}$. And, consequently, in the inauguration of new professional practices, from the establishment of dialogical relations and production of new knowledge $\mathrm{e}^{(26)}$.

In view of this, the importance of stages such as the VERSUS, which contribute to the understanding of the team and to the improvement of the student movement itself, is emphasized in the horizontal meeting between students of different professions. It is important to consider the fact that these stages led to the approach of the courses of the Health area in a multiprofessional and interdisciplinary way, in the search of the construction of common knowledge, preparing the student for the professional performance in multiprofessional teams. For the training of health workers, these experiences enable reflection, criticism, promotion of protagonism, teamwork and the relationship with other actors of the health system during the basic academic training ${ }^{(27)}$.

\section{Study limitations}

It is highlighted as a limitation of this study the reduced number of studies on extracurricular activities, especially the VER-SUS project. Therefore, it is suggested that future studies on the subject be carried out in order to provide subsidy for the inclusion of extracurricular activities in health CPPs.

\section{Contributions to the sectors of Nursing, Health or Public Policy}

With this study it became possible to understand the importance of extracurricular activities in training and acting in Nursing. This knowledge will serve as a basis for future extension projects developed at a higher level institution, focusing on public health.

\section{FINAL CONSIDERATIONS}

It was possible to identify the influences of the VER-SUS project in the training and performance of the nursing professionals, pointing out the revision of the CPP and the preparation of the teachers to consolidate this CPP as a way to carry out the training with emphasis in the SUS. This training in nursing still has challenges, such as the relationship between what has been learned in class and the practical reality encountered by academics. Thus, the need to carry out extracurricular experiences that allow the union between theory and practice, such as the VER-SUS project, since, even after the experience, nurses do not understand how the structuring of this network occurs.

With the performance of the VER-SUS, nurses felt more confident and confident of their professional inclination to Public Health. In this sense, they pointed to the project as an incentive for the Multiprofessional Residency Program.

It is extremely important that the experience brings influence, also, during professional practice, since this is, without doubt, the way to obtain a quality public health system, with professionals capable of understanding the subjects' needs, with a vision of care, thus reinforcing the importance of conducting this research. Also, it is hoped to seek subsidies that may contribute to the VER-SUS, as an education policy, which aims to strengthen the SUS, through academic training, for further discussions on the construction of the political projects of nursing courses in Brazil.

Therefore, the inclusion of the experience of the VER-SUS by the academics can provide training in nursing that meets the real needs of SUS users, with a view to building citizenship with quality, equality and dignity of the people.

\section{REFERENCES}

1. Winters JRF, Prado ML, Heidemann TSB. Nursing education oriented to the principles of the Unified Health System: perception of graduates. Esc Anna Nery[Internet]. 2016[cited 2018 Mar 20];20(2):248-53. Available from: http://www.scielo.br/pdf/ean/v20n2/ en_1414-8145-ean-20-02-0248.pdf 
2. Cruz RAO, Araujo ELM, Nascimento NM, Lima RJ, França JRFS, Oliveira JS. Reflections in the light of the complexity theory and nursing education. Rev Bras Enferm[Internet]. 2017[cited 2018 Mar 20];70(1):224-7. Available from: http://www.scielo.br/pdf/ reben/v70n1/en_0034-7167-reben-70-01-0236.pdf

3. Brasil. Ministério da Educação. Conselho Nacional de Educação. Resolução CNE/CES n 3, de novembro de 2001. Institui Diretrizes Curriculares Nacionais do Curso de Graduação em Enfermagem[Internet]. Brasília: CNE; 2001 [cited 2017 Jan 04]. Available from: http://portal.mec.gov.br/cne/arquivos/pdf/CES03.pdf

4. Fettermann FA. Vivência e estágio na realidade do Sistema único de Saúde: influências na formação e atuação dos enfermeiros[Dissertação]. Universidade Federal de Santa Maria; 2016.

5. Maranhão JH, Menezes FWP, Moura FJN, Silva MRF. Processo formativo VER-SUS Fortaleza: Encontro do viver e vivido (re) construindo saberes em saúde. Porto Alegre: Rede Unida; 2016.

6. Ramos TK, Nietsche EA, Salbego C, Fettermann FA, Piccin C. Experiences and stages in the unified health system reality - LRSUHS: case report. Rev Enferm UFPE[Internet]. 2016[cited 2017 May 08];10(12):4687-91. Available from: https://periodicos.ufpe.br/ revistas/revistaenfermagem/article/view/11539/13446

7. Backes DS, Souza MHT, Maerchiori MTC, Colomé JS, Backes MTS, Lunardi WDO. Sistema Único de Saúde idealizado versus o realizado: contribuições da Enfermagem. Rev Latino-Am Enfermagem[Internet]. 2014[cited 2017 Mar 22];22(6):1026-33. Available from: www.scielo.br/pdf/rlae/v22n6/pt_0104-1169-rlae-22-06-01026.pdf

8. Maranhão T, Matos IB. Experiences in the Brazilian National Health System (SUS) as events markers in the field of Collective Health. Interface[Internet]. 2018[cited 2018 Mar 15];22(64):55-66. Available from: http://www.scielo.br/pdf/icse/2017nahead/1807-5762icse-1807-576220160091.pdf

9. Gil AC. Como elaborar projetos de pesquisa. 6 ed. São Paulo: Atlas, 2017.

10. Minayo MCS. O Desafio do Conhecimento: pesquisa qualitativa em saúde. São Paulo: HUCITEC; 14. ed. 2014.

11. Bardin L. Análise de conteúdo. Lisboa: Edições 70; 2011.

12. Sardinha PL, Cuzatis GL, Dutra CT, Tavares CMM, Dantas CAC, Antunes CE. Permanent, continuous and of use Education: revealing its concepts. Enferm Glob[Internet]. 2013[cited 2018 Mar 22];29:324-40. Available from: http://scielo.isciii.es/pdf/eg/ v12n29/pt_revision $1 . p d f$

13. Dyson SE, Liu L, van den Akker O, O'Driscoll M. The extent, variability, and attitudes towards volunteering among undergraduate nursing students: implications for pedagogy in nurse education. Nurse Educ Pract[Internet]. 2017[cited 2018 Mar 22];23:15-22. Available from: eprints.mdx.ac.uk/21176/1/accepted_manuscript.pdf

14. Tao Y, Li L, Xu Q. Development of a nursing education program for improving Chinese undergraduates' self-directed learning: a mixedmethod study. Nurse Educ Pract[Internet]. 2015[cited 2018 Mar 22];23(11):15-22. Available from: http://www.nurseeducationtoday. com/article/S0260-6917(15)00244-0/fulltext

15. Oliveira CT, Santos AS, Dias AC. Percepções de Estudantes Universitários sobre a Realização de Atividades Extracurriculares na Graduação. Psicol Ciênc Prof[Internet]. 2016[cited 2017 Mar 24];36(4):864-76. Available from: http://www.scielo.br/pdf/pcp/ v36n4/1982-3703-pcp-36-4-0864.pdf

16. Silva MJ, Sousa EM, Freitas CL. Formação em enfermagem: interface entre as diretrizes curriculares e os conteúdos de atenção básica. Rev Bras Enferm[Internet]. 2011[cited 2017 Feb 18];64(2):315-21. Available from: http://www.scielo.br/pdf/reben/v64n2/ a15v64n2.pdf

17. Nóbrega-Therrien SM, Guerreiro MGS, Moreira TMM, Almeida MI. Projeto Político Pedagógico: concepção, construção e avaliação na enfermagem. Rev Esc Enferm USP[Internet]. 2010[cited 2017 Mar 22];44(3):679-86. Available from: http://www.scielo.br/pdf/ reeusp/v44n3/18.pdf

18. Carbogim FC, Oliveira LB, Püschel VAA. Critical thinking: concept analysis from the perspective of Rodger's evolutionary method of concept analysis. Rev Latino-Am Enfermagem[Internet]. 2016[cited 2017 Feb 18];24:2785. Available from: http://www.scielo. br/pdf/rlae/v24/pt_0104-1169-rlae-24-02785.pdf

19. Carvalho Y, Ceccin RB. Formação e Educação em Saúde: aprendizados com Saúde Coletiva. In: Campos, GWS, et al (Orgs.). Tratado de Saúde Coletiva. 2.ed. São Paulo: Hucitec; Rio de Janeiro: Fiocruz; 2008.

20. Brehmer LCF, Ramos FRS. Teaching-service integration: implications and roles in experiences of undergraduate courses in nursing. Rev Esc Enferm USP[Internet]. 2014[cited 2017 Apr 04];48(1):119-26. Available from: http://www.scielo.br/pdf/reeusp/v48n1/00806234-reeusp-48-01-118.pdf

21. Silva CT, Terra MG, Kruse MHL, Camponogara S, Xavier MS. Multi-professional residency as an intercessor for continuing education in health. Texto Contexto Enferm[Internet]. 2016[cited 2018 Mar 24];25(1):1-9. Available from: http://www.scielo.br/pdf/tce/v25n1/ en_0104-0707-tce-25-01-2760014.pdf

22. Peduzzi M, Norman IJ, Germani ACCG, Silva JAM, Souza GC. Interprofessional education: training for healthcare professionals for teamwork focusing on users. Rev Esc Enferm USP[Internet]. 2013[cited 2017 Jan 02];47(4):977-83. Available from: http://www. scielo.br/pdf/reeusp/v47n4/en_0080-6234-reeusp-47-4-0977.pdf 
23. Vasconcelos ACF, Stedefeldt E, Frutuoso MFP. Uma experiência de integração ensino-serviço e a mudança de práticas profissionais: com a palavra, os profissionais de saúde. Interface[Internet]. 2016[cited 2017 Mar 29];20(56):147-58. Available from: http://www. redalyc.org/pdf/1801/180142937013.pdf

24. Opitz SP, Martins JT, Telles Filho PCP, Silva AEBC, Teixeira TCA. O currículo integrado na graduação em enfermagem: entre o ethos tradicional e o de ruptura. Rev Gaúcha Enferm[Internet]. 2008[cited 2017 Apr 02];29:314-9. Available from: http://www. seer.ufrgs.br/RevistaGauchadeEnfermagem/article/viewFile/5598/3207

25. Garanhari ML, Valle ERM. O olhar do aluno habitando um currículo integrado de enfermagem: uma análise existencial. Cienc Cuid Saúde[Internet]. 2012[cited 2017 Apr 02];11(N.Supl):87-94. Available from: http://www.periodicos.uem.br/ojs/index.php/ CiencCuidSaude/article/view/17057/pdf

26. Martini JG, Massaroli A, Lazzari DD, Luz JH. Curriculum for undergraduate nursing courses: integrative literature review. Rev Pesq: Cuid Fundam[Internet]. 2017[cited 2017 Aug 22];9(1):265-72. Available http://www.seer.unirio.br/index.php/cuidadofundamental/ article/view/4044/pdf

27. Almeida Filho NM. Contextos, impasses e desafios na formação de trabalhadores em Saúde Coletiva no Brasil. Ciênc Saúde Colet[Internet]. 2013[cited 2016 Mar 12];18(6):1677-82. Available from: http://www.scielosp.org/pdf/csc/v18n6/19.pdf 